\title{
SUITMAs as an archive of the human past: educational implications
}

\author{
Magdalena Urbańska ${ }^{1}$ (D) Przemysław Charzyński ${ }^{1}$
}

Received: 11 February 2020 / Accepted: 24 January 2021 / Published online: 18 February 2021

(C) The Author(s) 2021

\begin{abstract}
Purpose The relics of the industry are widely used for educational and touristic purposes. There are many examples of brownfield sites turned into tourist attractions. Interest in post-industrial areas concerns not only an infrastructure and ruins but also the soil cover. Soils in such areas should be also considered as important element of this type of landscape due to the artefacts' stored. This article aim is to present educational potential of post-industrial soils and artefacts to be found there on the example of the area of "Polchem".

Methods and materials This publication is based on the analysis of soils' artefacts in the non-reclaimed area of former chemical plant. Photographic material and literature studies focus on technogenic soils and its functions. The history of "Polchem", industrial tourism and industrial archaeology as well as verbal communication of people associated with the company were important components of this publication.

Results and discussion Soils play many ecological functions, one of them is archiving human history. In this approach, archaeology is combined with soil science serving as a tool in archaeological research. Such cooperation within two scientific fields leads often to valuable scientific achievements. Relatively young post-industrial areas are generally out of interest of archaeology. However, they can form the basis of soil education activities targeted at a larger number of recipients.

Conclusions Soils within cities are interesting due to recorded marks of human activity. Artefacts in soils can be used in various ways. One of them is an educational purpose. "Polchem" area is out of use now so it can be accessed by visitors (students and teachers). Artefact's diversity allows for quick finding and recognition of industrial history of the former plant. In this way, it could be present an important soil function - protecting cultural heritage.
\end{abstract}

Keywords Urban soils $\cdot$ Industrial soils $\cdot$ Technosols $\cdot$ Soil education $\cdot$ Artefacts $\cdot$ Ecosystem services

\section{Introduction}

Soils have a very important role in our life and in the management of the human environment because they are one of the most valuable elements of terrestrial ecosystems. Awareness of this role appeared in the 1970s when the first attempts were made to define the functions of soils, to classify them and to perform physicochemical tests on them. The European Soil Chapter, issued in 1972, was a prototype for documents confirming the important role of the soil environment. Contemporary research deals with the subject of soils and

Responsible editor: Yongtao Li

Przemysław Charzyński

pecha@umk.pl

1 Department of Soil Science and Landscape Management, Nicolaus Copernicus University in Torun, Faculty of Earth Sciences and Spatial Management, Toruń, Poland their significance for humans through the prism of the quality, functions and ecosystem services of soils, often using these different terms interchangeably. Soils perform many ecological functions (Morel et al. 2015; Foley et al. 2005; Vitousek et al. 1997). Soil cover can be a testimony of human activity in agricultural development, settlement or industry. Soils are a reservoir of artefacts - a historical trace of human existence and management. As such, they can function as a research material not only for naturalists but also for archaeologists, historians and anthropologists. Moreover, they can be successfully promoted and used as a feature of touristic and educational attraction.

Soil functions are understood to be the benefits that soils offer to organisms, including humans. There are many divisions of these functions, of which two can be distinguished as the most frequently quoted. The first is the concept of W.E.H. Blum (2005), modified many times by the author since 1988, and it is probably the most popular concept in the European environment. Soil functions, according to Blum (2005), can 
be divided into the ecological and the non-ecological. Geological and cultural heritage is one of them. In American publications, e.g. Doran and Parkin (1994), there is a scheme of soil functions corresponding to their quality. According to the American scientists, one of the most important functions is to protect cultural heritage. According to the FAO (http://www.fao.org), basic soil functions (among them cultural heritage) can be distinguished. Karczewska (2012) divides soil functions into three groups: one consists of the issues cultural heritage, geological history and scientific and landscape values.

The European Commission COM (2002) 179 adopted the basic assumptions of a soil protection strategy. Soil functions were divided into five groups, including the cultural and $m a-$ terial environment of human activity.

According to Blum et al., soils represent and record a landscape's history using evidence of human activity as well as palaeontological evidence. It is essential of soils' cultural function (Blum et al. 2018).

Nowadays, there is a need to improve awareness of soil within cities as they are usually significantly altered by human activity. This can be achieved by a learning-by-doing strategy. Mobile Environmental Education Projects (MEEPs) are one example of promoting soil education (Siebe et al. 2017). Students can explore the soils of parks or schoolyards and its interaction with other environmental compartments using vehicles equipped with the materials they need. Using all their senses, such as touch, taste, smell, sight and hearing, young people can enhance their interest in soils (Siebe et al. 2017). In Europe, a number of soil awareness and education initiatives already exist from primary school education to informing decision makers and working with stakeholder groups (Towers et al. 2010). Soil science education is important for teaching knowledge and understanding of environmental systems and the value of environmental protection (Hallett and Caird 2017) but teaching ideas and practice are different around the world (Hartemink et al. 2014). A considerable part of this teaching is given to students from different disciplines (Hartemink et al. 2014) and from different stages of education (Prokof'eva 2018). Methods and forms of soil education should be adapted to the needs of recipients of a certain age and educational stage. According to Hartemink et al., these all require extra efforts to generate student interest and engagement in the subject and to find the educating soil scientists whose competence and creativity will also be balanced by a deep understanding of the applications of knowledge. This is a challenging task for all soil science educators (Hartemink et al. 2014).

The modern perspective on soil functions recognises the importance of understanding the soil environment as a food producer and gene reservoir, and as a record of the history of human activity via artefacts that can sometimes transform particular soils into a museum of sorts. Technogenic soils - those strongly transformed by human existence (other than agricultural activity) - are of just such formations (Charzyński and Hulisz 2013). Thus, these soils occur in urbanised and industrialised areas. Interest in technogenic soils has increased since the 1990 s, when more studies of these soils began to appear. A soil research group was established for urban, industrial, transport, mining and military areas-SUITMA. In essence, understanding SUITMAs involves understanding the needs that cities express, and how soils can be designed to support ecosystem services (Morel et al. 2015).

The aim of this article is to present the soil cover of a postindustrial area of the former chemical plant "Polchem" in a snapshot of the factory's cultural soil functions, its 70-year history of production technologies, its industrial infrastructure and its role in factory workers' lives. In this context, the question arises whether the post-industrial soils can be interesting educational objects for scientists, students and tourists. The studied area does not look like a museum of industry. It could be seen, rather as a museum of industrial activity without buildings, technology lines, chimneys or railroad tracks, but full of traces of that activity. According to Field et al. (2017), places like that could be an appropriate basis for a future teaching-research-industry-learning soil science curriculum model that extends beyond traditional discipline-based teaching.

\section{Methods and materials}

This publication is based on the analysis of soil artefacts, photographic material and literature studies focusing on technogenic soils and their functions, history of the "Polchem" factory, industrial tourism and industrial archaeology, as well as the verbal communication of people associated with the company.

Soils within "Polchem" area have large number of human artefacts which play important role in analysing these soils and its further educational implications. The procedures consisted of several stages: selection of the study area, field study, interpretation soils and artefacts and creating a model of possible interpretations of artefacts within the former chemical plant area. Artefacts were collected during various fieldworks from 2013 to 2019. An initial selection of artefacts was made. During this process, artefacts in the best condition were selected as well as artefacts interesting in appearance and useful for potential interpretation. Artefacts were divided into specific groups according to FAO (2006) due to its diversity. Its potential interpretation in relation to the history of industrial plant was proposed.

The scope of this article covers post-industrial soils on premises of the "Polchem" the Torun's "Company of NonOrganic Chemistry". The acronym "Polchem" is derived from the combination of the names Polish chemistry, defining the 
factory production profile. Torun $\left(53^{\circ} 01^{\prime} \mathrm{N} 18^{\circ} 36^{\prime} \mathrm{E}\right.$, ) is a city in the Torun Basin in Northern Poland, and covers an area of about $116 \mathrm{~km}^{2}$. The main factor in terrain relief is the activity of the Vistula River, which is connected with the occurrence of many flood terraces with inland dunes. Human activity has continued uninterrupted since the founding of the city in the thirteenth century. The soil cover (Fig. 1) is typical of most cities.

"Polchem" is located on the western outskirts of the city (Fig. 1). Geologically, it is a fragment of the third terrace of the Vistula's ice-marginal valley. The surface layer consists of well-sorted river sands transformed by wind. Part of the area is covered by large numbers of dune fields. Brunic Arenosols were developed from those sands and loamy sands that are not very rich in clay fraction and with a high susceptibility to chemical degradation (Bednarek et al. 2015). Due to the development of the city and industry, the soils of this area are classified as SUITMAs, according to the WRB soil classification (IUSS Working Group WRB 2015) as Spolic Technosols (Fig. 1). After the demolition of "Polchem" (Fig. 2) in this area, a shopping mall, the "Motoarena" sports facility and a petrol station were built. These objects occupy only part of the site of the former plant. Other than these three examples, the area is not used and is unreclaimed, despite various investment attempts.

Technosols are common in urban areas. They have large number of human artefacts which play important role in analysis of technogenic soils. Artefacts were produced, modified or transported from their source, by human activity. Its importance in soils was noticed by many scientists. J. Howard (Howard 2017) presented common types of anthropogenic

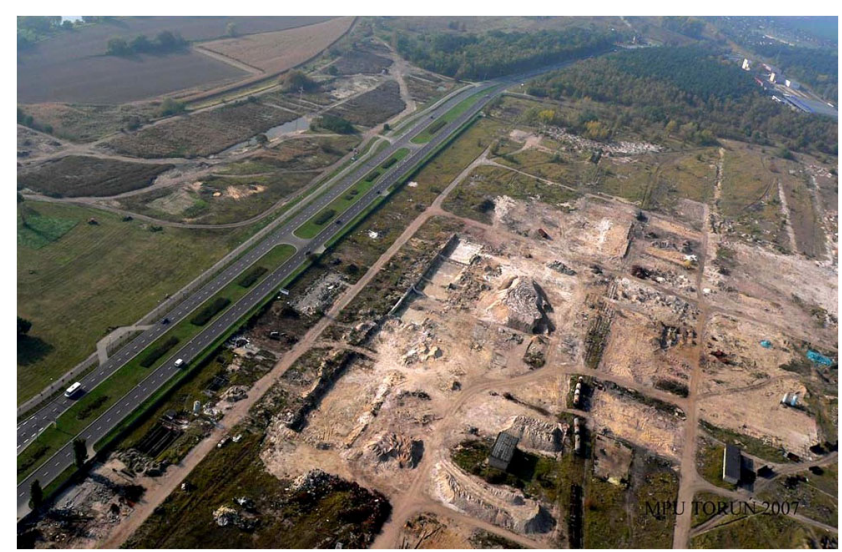

Fig. 2 Aerial view of "Polchem" after demolition (http://archiwum.mpuTorun.pl/index.php?m=gal\&id=13)

particles found in soils as well as description of artefacts and its diversity. Many examples of technogenic soils in Poland were presented by P. Charzyński, P. Hulisz and R. Bednarek (Charzyński et al. 2013). In this monograph, there are descriptions of various soils with artefacts related to human activities in urban, industrial, traffic, mining and military areas in Poland. Artefacts were described in Technosols of New York City (Shaw et al. 2010), Emilia Romagna Region in Italy (Antisari et al. 2014) as well as in mining areas of many countries (Echevarria and Morel 2015). In general, artefacts are described by many specialists according to their discipline. Nevertheless, the role of soils in storing and collecting traces of human activity is emphasised almost by every disciplines which are interested in humanly modified grounds (Edgeworth 2017).
Fig. 1 The soil map of Torun (Bednarek et al. 2003; Charzyński et al. 2018; Charzyński and Hulisz 2017). Explanations: 1 Brunic Arenols and Fluvic Gleysols (undisturbed and weakly transformed soils), 2 Urbic Technosols, Eutric Arenosols (Technic), 3 Spolic Technosols, Dystric Arenosols (Technic), 4 Fluvic Hortic Pheozems (Siltic or Loamic), Haplic Pheozems (Arenic or Siltic), 5 Ekranic Technosols, Relocatic Pheozems, 6 Ekranic Technosols, 7 Isolatic Technosols, 8 city boundaries, 9 surface waters, 10 area of former chemical plant 'Polchem'

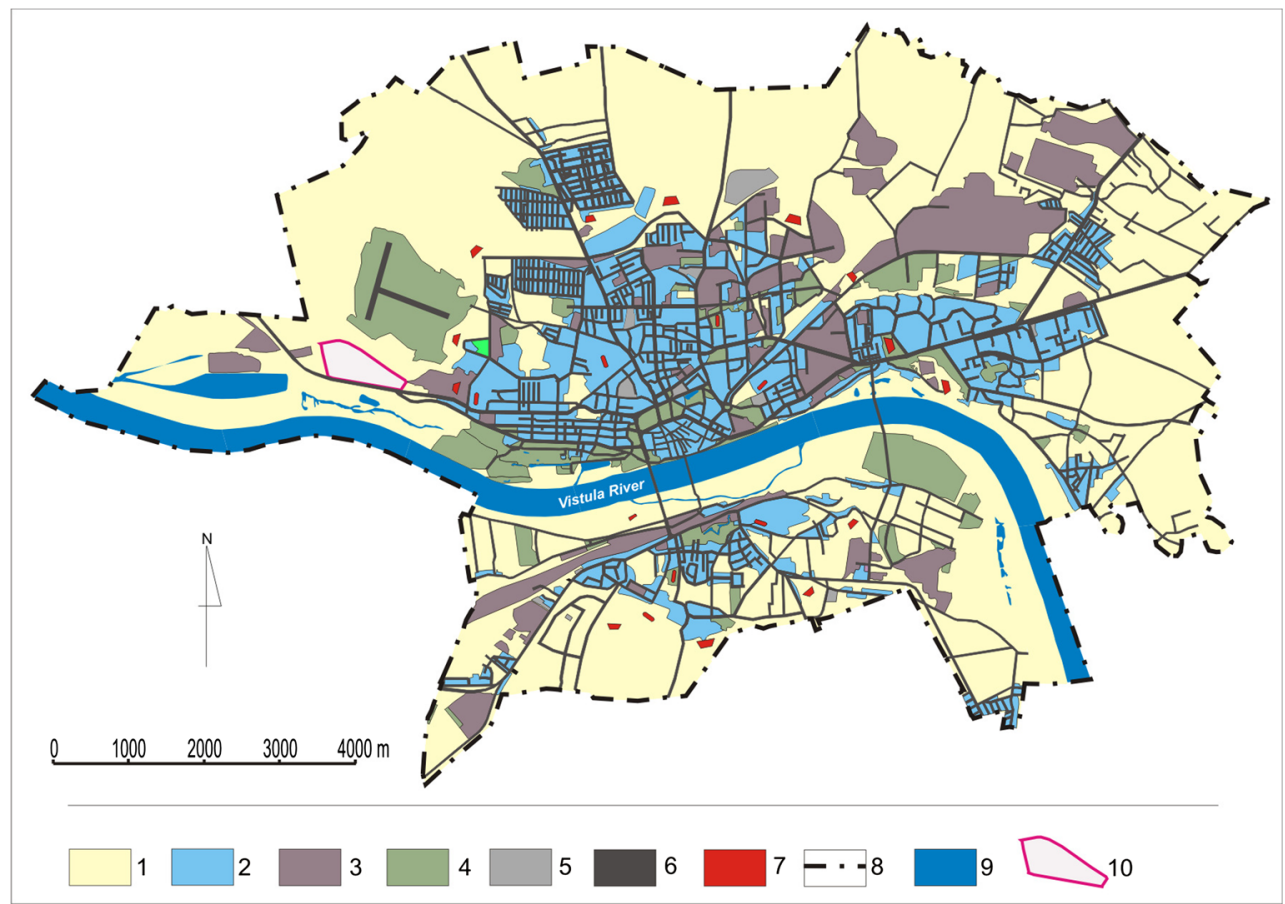




\subsection{Polchem: historical background}

The sulphuric acid company "Polchem" in Torun was the second of three such facilities built in Poland in the interwar period (Kruszka and Wartalski 1995). The Polish-Belgian joint-stock company was set up in 1929. In 1933, the company led to the construction and commission of "Polchem", a new chemical plant in Torun covering 60 ha. Initially, production included sulphuric acid of various concentrations, oleum (sulphur oxide), sodium and potassium sulphate (IV) and bisulphate (IV). The years 1970-1980 were not only a period of modernisation but also the beginning of environmental awareness. The negative impact on the environment was noted, and many various actions were taken to reduce it.

Until 1990, "Polchem" specialised in the production of several substances, such as simple dust superphosphate, technical and battery sulphuric acid, hydrochloric acid, chlorosulphonic acid, sodium sulphate, hydrosulphite, rongalite, zinc sulphate and reagent chemicals based on the technical chemicals it produced (Majchrzak et al. 2012).

The plant's final bankruptcy was declared by the court on 18.03.2003 (http://www.krs-online), but today, the plant website is still listing the available products on offer at the time it closed business. These are sodium hydrosulphide, sodium hydrosulphide for food purposes, sodium sulphate anhydrous technical and sodium sulphate (IV) heptahydrate (http://www.polchem.com.pl/produkty.html). All products are non-toxic and non-flammable but emit sulphur dioxide $\left(\mathrm{SO}_{2}\right)$ on being heated, and in addition to sulphate derivatives, most of them contain the heavy metals lead and arsenic, and some contain selenium (non-metal), cadmium, zinc and mercury. After 2003, the buildings were abandoned, workers were dismissed, and the entire infrastructure became post-industrial ruins (http://urbanqatsi.pl/Poland/polchem/Toruń-polchem. htm). It was decided to demolish the buildings, and the demolition material (debris) was sold for construction purposes.

\section{SUITMAs in education: results and discussion}

According to Siebe et al. (2017), three aspects must be considered to increase awareness about soils. In the human mind, there must be the need for "soil care". The participation of the body should be provided by experiences ("learning by doing"). Spiritual connections to soils create emotional links to them (by the soul). All three aspects can be perfectly fulfilled within the research area: the picture of soil disturbances can evoke a need for soil protection, field experience (with all precautions needed in polluted areas) and emotional engagement as a former industrial plant can be considered part of little homeland of Torun citizens. Nowadays, people are interested in the local environment. They are concerned about redeveloping lands and creating new open areas within cities. On the other hand, soil ecosystem services in cities are far more difficult to evaluate because they are not at the centre of political or economic interest (Levin et al. 2017). However, the fact is that brownfield investments are trendy, smart and popular. There are many examples of brownfields that have been reclaimed in recent decades (e.g. the Ruhr area in Germany, the Silesian area in Poland), but many of them are still out of use. The "Polchem" area is awaiting proper use. An educational function could be a practical possibility these days. According to Levin (Levin et al. 2017), there are many examples of places around the world for integrating soil scientific research and cultural reflection.

There are many different ways to present the importance of soils using various educational tools. The Senckenberg Museum of Natural History in Görlitz developed an international touring exhibition with the title "The Thin Skin of the Earth - Our Soils" (Xylander and Zumkowski-Xylander 2018) where many forms of educational approaches were presented. All forms were necessary to maintain the visitors' concentration and achieve maximum awareness, e.g. highquality models of soil organisms, digital and analogue hands-on-media, movies and VR. The exhibition was developed for a variety of target groups but has a special focus on families and school classes to change the visitor's attitude towards environmental issues following the concept of "from idea to action" (Xylander and Zumkowski-Xylander 2018).

To promote environmental awareness, environmental perception was utilised as the main tool to analyse public understanding of local environment (Santos et al. 2000). In São Paulo, a non-formal environmental education (EE) programme has been implemented in the natural conservation area through EE paradigms, which consider the objectives of education about, in and for the environment within cultural and natural perspectives. Various pedagogical tools were produced (Santos et al. 2000).

It should be noted that different groups of people are potential recipients so there is a need to introduce various educational methods. Bruce C. Ball shows the outcomes of selected methods of improved connections to soil issues for different groups (e.g. farmers, policy makers, scientists, children, adults (Ball et al. 2018). Both Prokof'eva (2018) and Świtoniak et al. (2018) present experiences of teaching soil science to students at different educational stages. It should be noted that this teaching requires special didactic materials, e.g. "Guidelines for soil description and classification" (Świtoniak et al. 2018).

"Digital natives"- students who are all "native speakers" of the digital language of computers, video games and the Internet (Prensky 2001) — need to adapt materials to their digital language. The Regional Environmental Center for Central and Eastern Europe (http://greenpack.rec.org/soil/index. 
shtml) has an online soil lesson that goes into: why soil is important, basic soil functions, problems and threats to the soil, and impacts of war on soils, and finishes with "what people can do" to protect soil for the future (Harrison et al. 2010). The Field Museum (http://www.fieldmuseum.org) has lessons for children called "underground adventure" (Harrison et al. 2010) with exercises in soil texture, temperature, compaction and percolation, factors that affect soil use and soil biodiversity. In Russia (Buyvolova et al. 2018), it was proposed to introduce the student competition (soil judging contest) in describing soils, and the team wins whose description is closest to the description expert. This could be an interesting way for students who will take part in "Polchem" soils education.

Increasingly, students have a desire to learn about soils with an emphasis on environmentally oriented applications (Harrison et al. 2010) so "Polchem" soils, with their cultural functions, could be interesting enough for them.

The Tea Bag Experiment - an interesting example of international project - shows that students willingly take part in such of undertakings. TeaTime4Schools was funded by Sparkling Science, a research programme of the Federal Ministry of Science, Research and Economy. The Tea Bag Experiment (http://www.teatime4science.org) was associated with the Tea Bag Index - a simple method to study decomposition of plant materials in soil. Students buried tea and investigated the relation between decomposition and microbial activity of the soil. The objective of the TeaTime4Schools project was to achieve a better understanding the role of microorganism in the decomposition process.

There are many examples of soil campaigns that make the target group aware of the importance of soil. The campaigns are part of the "soilution"-solution for soil degradation (Bramel 2012).

Table 1 lists a selection of artefacts found within the "Polchem" area, and possible interpretations by visitors (students or other recipients) in light of the industrial history of this former plant. This is a way to involve all the senses (mind, body and soul) to learn the history of the place through the area's soil cover. "Polchem" was turned into a site of poorly cleared rubble, but it is full of traces of its former activity that can be called "post-industrial artefacts". "Post-Polchem" soils, like many other soils of post-industrial areas, are characterised by the clear dominance of the function they perform at the moment - cultural functions. They are a treasury of knowledge hidden in artefacts that are important to the learning of the history of the place and human activity in this area.

The artefacts might be fragments of concrete, bricks and reinforcement elements that are the direct result of demolition work, but also production waste, used containers, and, finally, sulphur accumulated in the soil. In the area of the plant not only can traces of industrial activity be found but also fragments of transport infrastructure. The quantity of these materials indicates the important role that "Polchem" played in history. Post-industrial soils are a kind of record of events connected not only with production but with all industrial activity (fragments of reinforcements, debris from buildings, elements of railway tracks) (Fig. 4).

According to Howard (2017), artefacts are objects of $>$ $2.0 \mathrm{~mm}$ (whereas microartefacts are $0.25-2.0 \mathrm{~mm}$ ) that were produced, modified or transported from their source by human activity. Howard (2017) classified them into five types on the basis of composition: (1) carbonaceous, (2) calcareous, (3) siliceous, (4) ferruginous and (5) other. Due to its diversity, artefacts are divided into groups according to FAO (2006): (1) artisanal natural material; (2) industrial dust; (3) slag; (4) concrete fragments; (5) pavements and paving stones; (6) bricks, pottery fragments, and tiles; (7) metal fragments; (8) mixed materials; (9) organic garbage; (10) synthetic liquids; (11) synthetic solids; (12) waste liquids; (13) charcoals; and (14) other.

Most of these types can be found in the discussed area; moreover, they are common there (Table 1, Fig. 3, Fig. 4). This area can be seen as a living SUITMA laboratory that has been influenced for many years by the production of sulphuric acid and artificial fertilisers. In the new Polish soil classification (Kabała et al. 2019, 2020), two types of soil artefacts have been distinguished - "normal" (e.g. concrete, stones) and "reactive" (e.g. ash, slag, tailings), to reflect their different reactivity and toxicity in soil environments. There is an abundance of reactive artefacts (sulphur) in the study area, and its toxic properties can be observed (extreme $\mathrm{pH}$, spots completely devoid of vegetation) and shown to visitors (Fig. 5).

In view of the fact that the framework of cultural ecosystem services provides the opportunity to cooperate with other disciplines (Levin et al. 2017), "Polchem" can be considered also in the context of industrial archaeology - a field that has been developing since the mid-twentieth century and combining many disciplines (history of technology, archaeology, history of architecture, conservation of monuments, etc.). Soils can be an important storehouse of information and soil analysis can help archaeologists to date sites and get to know the major human activities (Vranova et al. 2015).

Industrial archaeology has become a basic tool for interpreting industrial heritage and technology (Labadi 2001; Januszewski 2010). The interest in industrial archaeology has led to the creation of museums in abandoned industrial facilities, as well as new forms of technical museumsecomuseums, which can be museums of time, space and humanity, showing the relation between man, nature and technology. Soil scientists are encouraged to discover new links between ecosystem functions and the unique cultural histories in which cities have evolved (Levin et al. 2017). It is the way that the area of "Polchem" can be seen.

The technological revolution, together with increasing ecology awareness, caused the liquidation of companies that had the potential to continue production but that were replaced by others that used more efficient and environmentally 
Table 1 Possible interpretations of artefacts within the "Polchem" area, for educational purposes

No. Artefact Example $\quad \begin{aligned} & \text { Artefact group } \\ & \text { (by division) }\end{aligned} \quad$ What the visitor should/could deduce? Reference to "Polchem"

1. Slag $\quad$ Fig. $4 \mathrm{a}, 4 \mathrm{i} \quad$ Slag

2. Sulphur

Fig. 4d, 4f, 4g, 4i Industrial dust

3. Synthetic solid Fig. 4a Synthetic solid

Figs. 3, 4h

Bricks, pottery

5. Chemical label Fig. $4 \mathrm{e}, 4 \mathrm{~b} \quad$ Mixed material

6. Plastic

Fig. 4a

Synthetic solid

7. Metal fragments

Fig. $4 \mathrm{~b}$

Metal fragments

8. Concrete fragments Fig. $4 \mathrm{~d}$ with sulphur

9. Concrete fragments Fig. 3

Concrete fragments

10. Glass fragments

Fig. $4 \mathrm{~b}, 4 \mathrm{c}, 4 \mathrm{~g}$

Other (glass)

11. Cable fragments Fig. $4 \mathrm{~h}$ fragments, tiles

fragments/industrial dust

It is an anthropogenic material; slag can be related to industry; slag changes the water and air characteristics of soil

It is a chemical and anthropogenic product; sulphur affects the chemical properties of soils; toxic to plants

It is an anthropogenic material; synthetic solid can come from human activity other than industry

Brick fragments could come from demolished buildings; they might be elements of industrial infrastructure

It is evidence of industrial activity related to the use of materials hazardous to people and the environment

It is an anthropogenic material; plastic could come from various sources

It is evidence of human activity; it could come from industry as well as from other sources

Concrete fragments could come from demolished buildings, and sulphur demonstrates the chemical processes performed as the human activity.

Concrete fragments are evidence of demolished buildings and human activity

This anthropogenic material could come from various human origins; it could be a type of rubbish

Synthetic solid/metal This anthropogenic material fragments comes from various human activities; it is evidence of human and industrial waste
Slag is a product of coal combustion in boiler rooms. Boiler plant rooms provided heating and hot water for "Polchem". It can also be a building material - "slag brick"

"Polchem" produced sulphur acid, so sulphur was a raw material in production process

In the plant, there were many possible uses of synthetic solids (e.g. floor covering, insulation material, synthetic worktops)

Bricks were a popular building material. "Polchem" was built from, among things, bricks, which are now a product of plant demolition

Fluorosilicic acid $\left(\mathrm{H}_{2} \mathrm{SiF}_{6}\right)$ was used in production of Sodium fluoride, Ammonium fluoride (acid), hydrofluoric acid and sodium fluorosilicate - important substances in the "Polchem" production structure. Many products were toxic, corrosive or irritant chemicals.

Plastic is a very common material. It was used in many different situations (as a building material; in office or lab equipment)

In the "Polchem" plant there were many metal constructions (sulphur furnaces, installation, railway infrastructure, etc.)

Sulphur as sulphur acid - the main product of "Polchem"-is corrosive. Sulphur efflorescence is very common not only on the surface but also inside concrete fragments

Concrete fragments come from the demolition of "Polchem". Concrete was used as a building material

Glass is a fragment of the plant's windows and other constructions made of this material. Glass bottles were used for storing acid

Metal elements were part of various industrial constructions (e.g. electrical cables) 


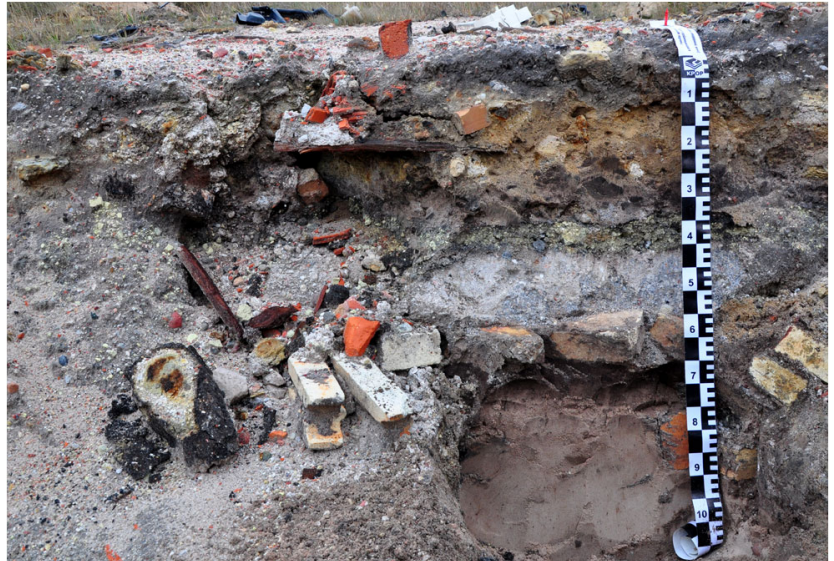

Fig. 3 Soil profile with abundance of artefacts within the former "Polchem" area friendly modern technologies. This process was often a cause of discontent among local communities (e.g. due to jobs losses). Nowadays, nostalgia for a plant where local people worked for decades could be another driving force in stimulating interest in the area and its SUITMAs and leading to growth of public awareness of soil degradation issues.

In 1978, the International Committee for the Preservation of Industrial Heritage (TICCIH) was established. In its name, the term "monuments" was replaced with "heritage", which was a stimulus for the development of industrial archaeology.

The premises of Torun's plant is now a feature of the city's landscape and part of local memory. The soil cover is a 70year-old record of the industrial activities. There are important links between industrial archaeology and contemporary
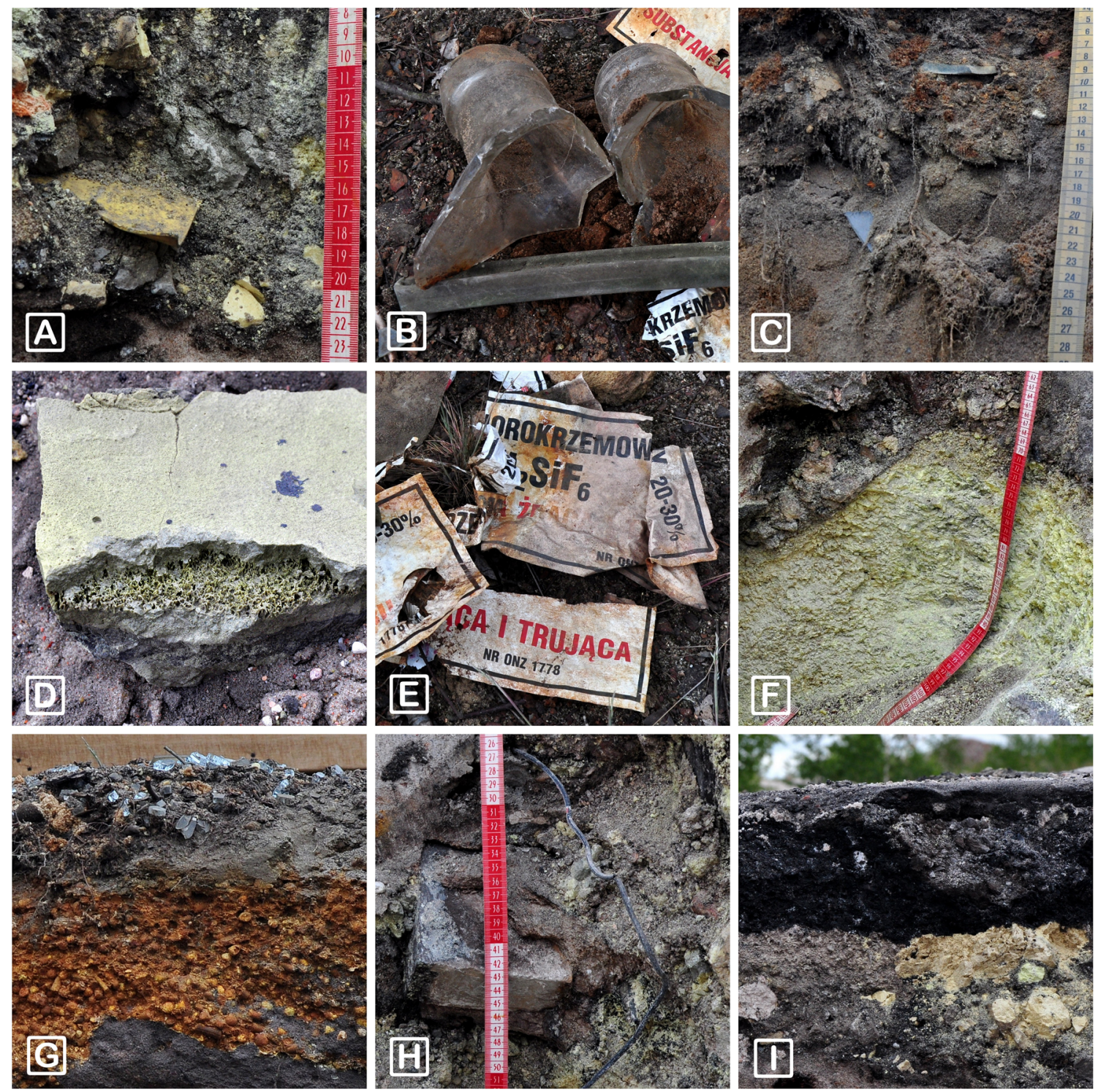

Fig. 4 Artefacts found in soils within the former "Polchem" area: A Synthethic solid and slag; B Metal and glass fragments; C Glass fragments; D Concrete fragments with sulphur, industrial dust; E

Chemicals labels; F Sulphur; G glass fragments and sulphur; H Cable fragments, bricks, pottery fragments, tiles; I Slag, Industrial dust 


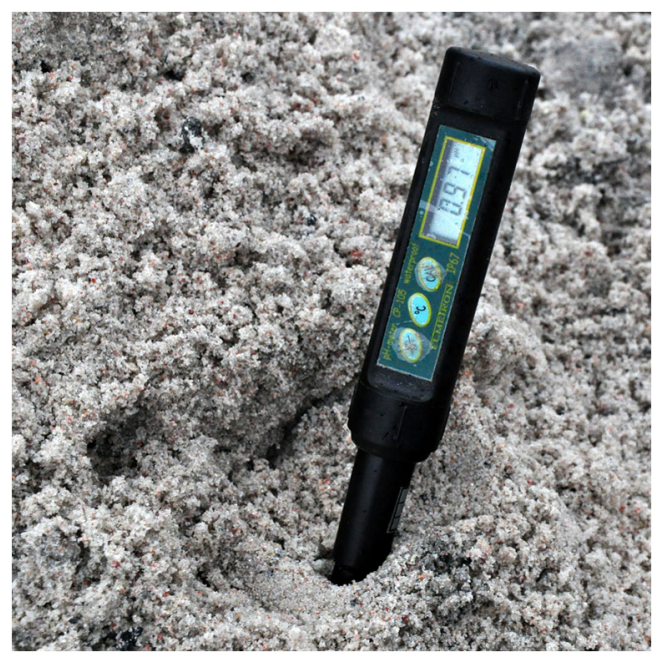

Fig. 5 Extreme soil pH measured within the former "Polchem" area

society with its ideas, needs and plans for the development of post-industrial areas.

Industrial archaeology is an initiator and coordinator of research in the humanities and the technical, natural and economic sciences, and is seen as an interdisciplinary field in which specialist knowledge from many scientific fields is treated as a potential background for research. It certainly has a place for cultural studies into soil functions, as well as other branches of soil science. The soil cover of the "Polchem" site, and the artefacts and the history of this place, should be not only a subject of scientific research but could also be defined as cultural tourism with educational implications for post-industrial facilities. Industrial tourism and educational activities aim to provide knowledge about various elements of the industrial landscape. This kind of spaces includes not only buildings, installations and infrastructure but also the human factor - curiosity about the living conditions of the people who were "inside" the industrial centre in the past or are there in the present. Despite the fact that "Polchem" does not exist today, its history is written in the natural environment. The soils are features that perfectly preserve evidence of human activity. In connection with artefacts occurring in the soil, this could be a perfect reflection of the processes going on during industrial production. In such an environment, an educational and touristic approach can use the principles of gamification (Urbańska et al. 2019) to encourage engagement. Most modern students require interaction and competition because social media and virtual reality games have changed the way young people perceive the real world, and that also includes the education process, which should be supported by elements of gamification. It seems only natural to make use of such strong motivation in order to enhance the experience of field activities related to urban soil science.

According to Harrison et al. (2010) "education, whether formal or informal, is key to developing an understanding of any subject."

\section{Conclusions}

The "Polchem" soil cover has recorded the history of the plant. Nowadays, the world is being forced to solve many ecological problems. People are aware of the dangers of global warming and air pollution but they do not fully realise that soil resources and soil protection are equally important for humankind. The soil scientist community should paid much more attention to soil education to make people aware of the importance of soil, both in their surroundings and on a global scale. Soils are everywhere. Around the cities, there are unused brownfields, and these places could become a living laboratory for soil education. There are many possibilities in these areas to provide information about the process of soil evolution, destruction and protection, and other issues. The possibility to interest the recipient in artefacts that are often seen as ordinary waste is one of the options hidden in SUITMAs. The cultural functions of soils could, in combination with the artefacts found in former industrial areas, extend the tourist and educational offer of the city, in addition to being a place of scientific research addressed to different recipients.

\section{Declarations}

Informed consent Informed consent was obtained from all individual participants included in the study.

Conflict of interest The authors declare that they have no conflict of interest.

Human and animal rights Research did not involve human participants and/or animals.

Open Access This article is licensed under a Creative Commons Attribution 4.0 International License, which permits use, sharing, adaptation, distribution and reproduction in any medium or format, as long as you give appropriate credit to the original author(s) and the source, provide a link to the Creative Commons licence, and indicate if changes were made. The images or other third party material in this article are included in the article's Creative Commons licence, unless indicated otherwise in a credit line to the material. If material is not included in the article's Creative Commons licence and your intended use is not permitted by statutory regulation or exceeds the permitted use, you will need to obtain permission directly from the copyright holder. To view a copy of this licence, visit http://creativecommons.org/licenses/by/4.0/.

\section{References}

Antisari LV, Papa GL, Ferronato C, Falsone G, Vianello G, Dazzi C (2014) In situ remediation of polluted Spolic Technosols using $\mathrm{Ca}$ $(\mathrm{OH})_{2}$ and smectitic marlstone. Geoderma 232-234:1-9

Ball BC, Hargreaves PR, Watson CA (2018) A framework of connections between soil and people can helpimprove sustainability of the food 
system and soil functions. Ambio 47:269-283. https://doi.org/10. 1007/s13280-017-0965-Z

Bednarek R, Charzyński P, Zawadzka A (2003) Soils within Toruń Urban area. SUITMA 2003 abstracts book, Nancy pp 229-230

Bednarek R, Świtoniak M, Mendyk $Ł$ (2015) Soil types and subtypes map circa 1:700 000. In: Kozieł Z (ed) Atlas of the KuyavianPomeranian Voivodeship. Nicolaus Copernicus University Press, Toruń, pp 54-55

Blum WEH (2005) Functions of soil for society and environment. Rev Environ Sci Biotechnol 4:75-79. https://doi.org/10.1007/s11157005-2236-x

Blum WEH, Schad P, Nortcliff S (2018) Essentials of Soil Science. Soil formation, functions, use and classification (World Reference Base, WRB). Borntraeger Science Publishers, Stuttgart

Bramel EK (2012) Save our soils project S.O.S. http://saveoursoils.com. Accessed 12 Jan 2020.

Buyvolova A, Prokofieva TV, Kurbanova FG (2018) Guide for competition field description and diagnostic of soils. Educationalmethodical textbook. Lomonosov Moscow State University, Faculty of soil Science, Moscow [In Russian]

Charzyński P, Hulisz P (2013) Soils forming on the buildings in Torun. In: Charzyński P, Hulisz P, Bednarek R (eds) Technogenic soils of Poland. Polish Society of Soil Science, Toruń, pp 81-94

Charzyński P, Hulisz P (2017) The case of Toruń, Poland. In: Levin MJ, K-HJ K, Morel JL, Burghardt W, Charzyński P, Shaw RK (eds) Soils within Cities. Global approaches to their sustainable management - composition, properties, and functions of soils of the urban environment. Schweizerbart Science Publisher, Stuttgart, pp 123128

Charzyński P, Hulisz P, Bednarek R (eds) (2013) Technogenic Soils of Poland. Polish Society of Soil Science, Torun

Charzyński P, Bednarek R, Hudańska P, Świtoniak M (2018) Issues related to classification of garden soils from the urban area of Torun, Poland. Soil Sci Plant Nutr 64(2):132-137. https://doi.org/ 10.1080/00380768.2018.1429833

Council of Europe (1972) Resolution 72/19 of the 26th May 1972 of the Council of Europe, the "European Soil Charter"

Doran JW, Parkin TB (1994) Defining and assessing soil quality. In: Doran JW, Coleman DC, Bezdicek DF, Stewart BA (eds) Defining Soil Quality for a Sustainable Environment. SSSA, Inc., Madison. Soil Quality for the Environmental Health. http:// soilquality.org/functions/function_lists.html. Accessed 10 Nov 2019.

Echevarria G, Morel JL (2015) Technosols of mining areas. Tôpicos Ciência Solo 9:92-111

Edgeworth M (2017) Humanly modified ground. In: Della Sala DA, Goldstein MI (eds) The Encyclopedia of the Anthropocene. Oxford, Elsevier, pp 157-161 (Pre-publication version)

European Commission: Towards a Thematic Strategy for Soil Protection (2002) Communication from the Commission to the Council, the European Parliament, Brussels: the Economic and Social Committee and the Committee of the Regions

Field DJ, Yates D, Koppi AJ, McBratney AB, Jarrett L (2017) Framing a modern context of soil science learning and teaching. Geoderma 289:117-123

Foley JA, DeFries R, Asner GP, Barford C, Bonan G, Carpenter SR, Chapin SF, Coe MT, Daily GC, Gibbs HK, Helkowski JH, Holloway T, Howard EA, Kucharik CJ, Monfreda C, Patz JA, Prentice CI, Ramankutty N, Snyder PK (2005) Global consequences of land use. Science 309:570-574

Food and Agriculture Organization of the United Nations (2006). Soil Functions: http:// www.fao.org/resources/infographics/ infographics-details/en/c/284478/. Accessed 12 Nov 2019.
Hallett H, Caird SP (2017) Soil-net: development and impact of innovative, open, online soil science educational resources. Soil Sci 182:188-201. https://doi.org/10.1097/SS0000000000000208 https://pdfs. semanticscholar.org/8662/fbf97c72cb42e115bdb4a116e7dd24ec7221. pdf.

Harrison R, Strahm B, Xiu Yi (2010) Soil education and public awareness Verheye W.H (ed) Soils, Plant Growth and Crop Production. Vol. III. Encyclopaedia of Life Support Systems (EOLSS), EOLSS publishers/UNESCO, UK (2010), pp. 196-218

Hartemink AE, Balks MR, Chen Z-S, Drohan P, Fielde DJ, Krasilnikov P, David J, Lowe DJ, Rabenhorst M, Van Rees K, Schadi P, Schipper LA, Sonneveld M, Walter C (2014) The joy of teaching soil science. Geoderma 217-218:1-9

Howard J (2017) Anthropogenic soils. Progress in Soil Science. SpringerVerlag, New York

http://archiwum.mpu-Torun.pl/index.php?m=gal\&id=13. Accessed 02 Dec 2019

http://urbanqatsi.p1/Poland/polchem/Toruń-polchem.htm. Accessed 02 Dec 2019

http://www.krs-online.com.pl/msig-1653-3254-o.html. Accessed 14 Nov 2019

http://www.polchem.com.pl/produkty.html. Accessed 14 Nov 2019

http://www.teatime4science.org. Accessed 31 Aug 2020

IUSS Working Group WRB (2015) World Reference Base for Soil Resources 2014, update 2015. International soil classification system for naming soils and creating legends for soil maps. World Soil Resources Reports No. 106. FAO, Rome

Januszewski S (2010) Industrial archaeology - its birth and subject of research. In: Meetings with monuments (Spotkania z zabytkami) 34:6-16. [In Polish]

Kabała C, Charzyński P, Chodorowski J, Drewnik M, Glina B, Greinert A, Hulisz P, Jankowski M, Jonczak J, Łabaz B, Łachacz A, Marzec M, Mendyk $Ł$, Musiał P, Musielok $Ł$, Smreczak B, Sowiński P, Świtoniak M, Uzarowicz Ł, Waroszewski J (2019) Polish Soil Classification, 6th edition - principles, classification scheme and correlations. Soil Sci Annu 70(2):71-97

Kabała C, Greinert A, Charzyński P, Uzarowicz Ł (2020) Technogenic soils - soils of the year 2020 in Poland. Concept, properties and classification of technogenic soils in Poland. Soil Sci Annu 71(4): 267-280

Karczewska A (2012) Soil protection and reclamation of degraded areas. WUP, Wroclaw [In Polish]

Kruszka F, Wartalski A (1995) Torun's Company of non-organic chemistry "Polchem". In: Cards from the history of the Polish chemical industry - History of the Polish non-organic industry IV. Association of Chemical Industry Engineers and Technicians, Warsaw, pp 278302 [In Polish]

Labadi S (2001) Industrial archaeology as historical archaeology and cultural anthropology. Pap Ins Archaeol 12:77-85. https://doi.org/ $10.5334 /$ pia. 162

Levin MJ, Kim K-H, Morel JL, Burghardt W, Charzynski P, Shaw RK (eds) (2017) Soils within Cities. Global approaches to their sustainable management - composition, properties, and functions of soils of the urban environment. Schweizerbart Science Publisher, Stuttgart

Majchrzak J, Lubiewa-Wieleżyński W, Rejewski P (2012) Great chemical synthesis industry. In: Cards from the history of the Polish chemical industry - History of the Polish non-organic industry in years 1980-2010 XX, Association of Chemical Industry Engineers and Technicians, Warszawa, pp 13-49. [In Polish]

Morel JL, Chenu C, Lorenz K (2015) Ecosystem services provided by soils of urban, industrial, traffic, mining, and military areas (SUITMAs). J Soils Sediments 15(8):1659-1666 
Prensky M (2001) “Digital Natives, Digital Immigrants, Part II: Do They Really Think Differently?" On the Horizon, vol. 9, no. 6: 15-24

Prokof'eva TV (2018) Experience of the teaching of soil classification systems to students at different stages of education. Bull Geography 14:85-90. https://doi.org/10.2478/bgeo-2018-0008

Santos JE, Sato M, Pires JSR, Maroti P (2000) Environmental education praxis toward a natural conservation area. Rev Bras Biol 60(3):361372. https://doi.org/10.1590/S0034-71082000000300001

Shaw RK, Wilson MA, Reinhardt L, Isleib J (2010) Geochemistry of artifactual coarse fragment types from selected New York City soils. Proceedings of the 19th World Congress of Soil Science: Soil solutions for a changing world, Working Group 3.3. Soils in urban and industrial areas, Brisbane, pp 25-27

Siebe C, Cram S, Palomino LM (2017) Enhancing awareness about the importance of urban soils. In: Lal R, Stewart BA (eds) Urban soils. CRC Press, Boca Raton, pp 351-372

Świtoniak M, Kabała C, Karklins A, Charzyński P (eds) (2018) Guidelines for soil description and classification. Central and Eastern European Students' Version. Polish Society of Soil Science, Toruń
Towers W, Creamer R, Broll G, Darboux F, Duewel O, Hallett SH, Houskova B, Jones A, Lobnik F, Micheli E, Zdruli P (2010) Soil awareness and education: developing a pan European approach. In: Gilkes RJ, Prakongkep N (eds) 19th World Congress of Soil Science, Soil Solutions for a Changing World. Conference paper, Brisbane

Urbańska M, Sojka T, Charzyński P, Świtoniak M (2019) Digital media in soil education. Geogr Tour 7(1):41-52

Vitousek PM, Mooney HA, Lubchenco J, Melillo J (1997) Human domination of earth's ecosystems. Science 277(5325):494-499

Vranova V, Danso MT, Rejesek K (2015) Soil scientific research methods used in archaeology - promising soil biochemistry: a mini-review. Acta Univ Agric Silvicult Mendelianae Brun 63(4): $1417-1426$

Xylander WER, Zumkowski-Xylander H (2018) Increasing awareness for soil biodiversity and protection. The international touring exhibition "The Thin Skin of the Earth". Soils Organ 90(2):79-94

Publisher's note Springer Nature remains neutral with regard to jurisdictional claims in published maps and institutional affiliations. 